\title{
An Empirical Study on the Influencing Factors of Independent Innovation of Chinese Large and Medium-sized Industry Enterprises
}

\author{
Xin Zhu \\ Department of Management, Guangxi University of Science and Technology, Liuzhou, P.R.China \\ 5266736@qq.com
}

Keywords: Large and medium-sized industry enterprises; Co-integration analysis; Influencing factors

Abstract: Using the co-integration method, the influencing factors on independent innovation of Chinese large and medium-sized industry enterprises are discussed in this paper. The result shows that level of development of large and medium-sized industry enterprises, R\&D investment, FDI, intellectual property protection and investment in human capital greatly affect independent innovation of Chinese large and medium-sized industry enterprises while enterprise scale fails to prove significant correlation.

\section{Introduction}

Xi Jin Ping pointed out that because global competition in the overall national strength had become increasingly fierce, our country must embark on the road of independent innovation, accelerating the shift from elements-driven development to innovation-driven development. Innovation is not only the soul of enterprises and guarantee for products to gain lasting vitality but also is of utmost importance to development of enterprises. In order to survive in the international competition, Chinese large and medium-sized industry enterprises only carry out independent innovation. An empirical study on the influencing factors of independent innovation of Chinese large and medium-sized industry enterprises is made in this paper.

\section{Research Hypothesis}

\subsection{R\&D Investment and Independent Innovation}

Active R\&D activities can bring more new technology and competitiveness to enterprises. Hausmanetal (1984) concluded that R\&D investment had a positive role in promoting output of patent. Liu He Dong (2006) discovered there was a significant positive correlation between R\&D investment and independent innovation of Chinese large and medium-sized industry enterprises ${ }^{[1]}$. Based on the above analysis, the following hypothesis is proposed:

H1: There is a positive correlation relationship between R\&D investment and independent innovation of Chinese large and medium-sized industry enterprises.

\subsection{Enterprise Scale and Independent Innovation}

Large-scale enterprises own abundant capital, advanced technology and equipment, advanced management experience, human capital of high quality, strong anti-risk ability. Smyth and Samuels (1972) found that a significant increase in innovation output result from increase in enterprise scale ${ }^{[2]}$.Tsai found large-scale enterprise had a higher competitive advantage in terms of output than medium-sized companies ${ }^{[3]}$. Based on the above analysis, the following hypothesis is proposed:

H2: There is a positive correlation relationship between enterprise scale and independent innovation of enterprises. 


\subsection{Investment in Human Capital and Independent Innovation}

Schultz (1962) maintained that people with a higher level of education or highly skilled workers used their own experience and skills to put intangible factors into direct productivity. The reason why human capital affects the level of innovation is that enterprises that concentrate more quality human capital will lead to innovative knowledge, thoughts, ideas are widely disseminated among the enterprise, and then a good corporate culture of innovation and innovative atmosphere will be formed. It is assumed that:

H3: There is a positive correlation relationship between investment in human capital and independent innovation of Chinese large and medium-sized industry enterprises.

\subsection{Level of Development of Industry and Independent Innovation}

The development of the industry provides the necessary material basis and raw technology accumulation for independent innovation, and is a powerful guarantee for promoting independent innovation. Throughout the history of development of countries, industry development and technological progress is synergistic and inseparable. It is assumed that:

H4: There is a positive correlation relationship between level of development of large and medium-sized industry enterprises and independent innovation of Chinese large and medium-sized industry enterprises.

\subsection{Intellectual Property Protection and Independent Innovation}

Intellectual property protection can accelerate the accumulation of knowledge, providing rich and comprehensive information resources for enterprises conducting independent innovation, promoting exchanges and cooperation between enterprises and the outside world. Liu He Dong found that there was a highly strong correlation between intellectual property protection and independent innovation of Chinese large and medium-sized industry enterprises ${ }^{[4]}$.The following hypothesis is proposed:

H5: There is a positive correlation relationship between intellectual property protection and independent innovation of Chinese large and medium-sized industry enterprises.

\subsection{FDI and Independent Innovation}

The reason why FDI result in technology spillover is that after learning and imitating new products, new technologies and production processes of foreign company, the host country increased innovation awareness, and develop products competing for foreign companies ${ }^{[5]}$.Hu concluded that FDI had an indispensable role in increasing output of patent ${ }^{[6]}$. The following hypothesis is proposed:

H6: There is a positive correlation relationship between FDI and independent innovation of Chinese large and medium-sized industry enterprises.

\section{Research Method and Index Selection}

\subsection{Co-integration Analysis}

Co-integration analysis is a new technology that is used for setting estimating and testing dynamic model. In practical analysis, firstly, stationarity of variables of time series and their difference sequence is tested; secondly the co-integration relationship between variables is tested. Finally, granger causality relationship of time series variables is further inspected.

\subsection{Variables and Data}

Specific indicators are seen in table 1 : 
Table 1. Measurable variables of influencing factors and specific indicators

\begin{tabular}{|l|l|c|}
\hline Measurable Factors & Specific Factors & Symbolic Code \\
\hline $\begin{array}{l}\text { Level of independent } \\
\text { innovation }\end{array}$ & $\begin{array}{l}\text { New product output value accounted for the } \\
\text { proportion of gross industrial output value }\end{array}$ & $\mathrm{Y}$ \\
\hline R\&D investment & $\begin{array}{l}\text { R\&D expenditure accounted for the } \\
\text { proportion of sales revenue }\end{array}$ & $\mathrm{R}$ \\
\hline Enterprise scale & $\begin{array}{l}\text { Average assets of large of medium-sized } \\
\text { industry enterprises }\end{array}$ & $\mathrm{H}$ \\
\hline $\begin{array}{l}\text { Investment in human } \\
\text { capital }\end{array}$ & $\begin{array}{l}\text { Scientists and engineers accounted for the } \\
\text { proportion of personnel of activities of } \\
\text { science and technology }\end{array}$ & $\mathrm{E}$ \\
\hline $\begin{array}{l}\text { Level of development of } \\
\text { large and medium-sized } \\
\text { industry enterprises }\end{array}$ & $\begin{array}{l}\text { Industrial added value accounted for the } \\
\text { proportion of gross industrial output value, }\end{array}$ & $\mathrm{P}$ \\
\hline $\begin{array}{l}\text { Intellectual property } \\
\text { protection }\end{array}$ & $\begin{array}{l}\text { Granted patent accounted for proportion of } \\
\text { applied patent }\end{array}$ & $\mathrm{F}$ \\
\hline FDI & Foreign Direct Investment & \\
\hline
\end{tabular}

Time series is used and annual data from 1996 to 2010 is selected as the research sample in this paper, while the data is derived from the statistical material contained "China Statistical Yearbook", "China Statistical Yearbook of Science and Technology." In order to eliminate heteroscedasticity phenomenon, all variables are naturally transformed. Level of independent innovation, R\&D investment, enterprise scale, investment in human capital, level of development of large and medium-sized industry enterprise, intellectual property protection, FDI is replaced with LNY, LNR, LNS, LNH, LNF, LNP, LNE.

\section{Empirical Analysis}

\subsection{Stationarity Test}

As is seen from the test, at the $5 \%$ significance level, the level sequence of all variables are non-stationary, and their first order sequence of differences is stationary, which means co-integration test can be done smoothly.

\subsection{Co-integration Test}

Co-integration test are used to determine whether there is further co-integration relationship between the variables. Johansen test method is used to determine whether there is co-integration relationship between variables. The results of co-integration test results are shown in table 2.

Table 2. The results of johansen co-integration test

\begin{tabular}{|l|l|l|l|l|}
\hline Eigenvalue & $\begin{array}{l}\text { Likelihood } \\
\text { Ratio }\end{array}$ & $\begin{array}{l}\text { 5\%Percent } \\
\text { Critical Value }\end{array}$ & $\begin{array}{l}\text { 1\%Percent } \\
\text { Critical Value }\end{array}$ & $\begin{array}{l}\text { Hypothesized } \\
\text { No. of CE(s) }\end{array}$ \\
\hline 0.9543 & 94.34532 & 76.56 & 85.43 & None** \\
\hline 0.8765 & 56.67509 & 53.34 & 61.78 & At most $1^{*}$ \\
\hline
\end{tabular}

Indicates rejecting the null hypothesis at the $5 \%$ significance level.

As can be seen from Table2, these variables are co-integrated at the $5 \%$ significance level. Co-integration equation is as follows:

$$
L N Y=0.632 L N R+0.04 L N S+0.344 L N H+O .528 L N E+0.153 L N P+0.24 L N F
$$


As can be seen from above co-integration equation, there is a long-term equilibrium relationship between independent innovation of Chinese large and medium-sized industry enterprises and its influencing factors.

The influence on independent innovation of Chinese large and medium-sized industry enterprises caused by R\&D investment and the level of development of large and medium-sized industry enterprise is seriously obvious. If $R \& D$ investment increase $1 \%$, the level of independent innovation will increase $0.632 \%$.If the level of development of large and medium-sized industry enterprise increase $1 \%$, the level of independent innovation will increase $0.528 \%$.

The influence on independent innovation of Chinese large and medium-sized industry enterprises caused by investment in human capital, intellectual property protection and FDI is positive. If investment in human capital increase $1 \%$, the level of independent innovation will increase $0.344 \%$.If intellectual property protection increase $1 \%$, the level of independent innovation will increase $0.153 \%$, If FDI increase $1 \%$, the level of independent innovation will increase $0.24 \%$.

The influence on independent innovation of Chinese large and medium-sized industry enterprises caused by enterprise scale is inconspicuous. If enterprise scale increase $1 \%$, the level of independent innovation will increase $0.04 \%$.

\section{Conclusions}

Hypothesis 1, 3, 4, 5, 6 all get past the inspection. Hypothesis 2 fails to pass the test.

The reason why hypothesis 2 fails to pass the test is that: large-scale enterprises often have a complex organizational structure and guarded huge bureaucracy; the flexibility of large-scale enterprises is bad; delayed reaction to rapidly changing market information and high cost of communication are often seen in large scale enterprises.

\section{Acknowledgements}

This research was financially supported by the Foundation of Guangxi Educational Committee (Grant No: SK13ZD030)

\section{References}

[1] Smyth D. J. , Samuels J. M. , "Patents, Profitability, Liquidity and Firm Size”. Applied Economics, vol.4, pp.77-86, 1972

[2] Liu He Dong. Empirical analysis on relationship between intellectual property protection and enterprise innovation”, Statistics and Decision, vol.16, pp.125-127, 2008

[3] Blomstrm, “Technology Transfer and Spillovers? Does Local Participation with Multinationals Matter? ”, European Economic Review, vol. 43, pp. 915-923, 1998

[4] $\mathrm{Hu}$, "R\&D and Technology Transfer : Firm-Level Evidence from Chinese Industry", Review of Economics and Statistics, vol.8, pp.80-86, 2005

[5] Liu He Dong. the Co-integration Analysis between the R\&D Input and the Independent Innovation Ability”, Science of Science and Management of S. \& T., vol.27, pp.21-25, 2006 